УДК 616.314-002-084:616.899-053.2/.6

Чухрай Н.Л. ${ }^{1}$, Безвушко Е.В. ${ }^{1}$, Дутко Г.3. ${ }^{2}$, Стадник У. О. ${ }^{1}$, Мусій-Семенців Х.Г. ${ }^{1}$

ОСОБЛИВОСТІ ПРОФІЛАКТИКИ КАРІЕСУ ЗУБІВ У ДІТЕЙ 3 ОЛІГОФРЕНІЄЮ

${ }^{1}$ Львівський національний медичний університет імені Данила Галицького, Львів, Україна

${ }^{2}$ Комунальне некомерційне підприємство «Стоматологічна поліклініка №4», Львів, Україна

\section{Актуальність}

Карієс зубів і захворювання тканин пародонта досі залишаються однією з актуальних проблем дитячої стоматології [1-3]. Відомо, що на розвиток карієсу і хвороб пародонта в дітей потужно впливає соматична патологія, на тлі якої виникають різноманітні порушення метаболічного гомеостазу в організмі дітей і яка $€$ патогенетичною основою розвитку стоматологічних хвороб і їхніх ускладнень [4-6].

Серед дітей із соматичною патологією особливою категорією $€$ діти із психоневрологічними розладами [7;8]. Наукові дослідження свідчать про зв'язок розумових порушень зі стоматологічною патологією в дітей. Установлено, що в дітей від 2 до 15 років поширеність карієсу коливається в межах від 72,5\% до 77,3\%, частота гінгівіту в дітей віком $12-15$ років складає $89,74 \%$ $86,58 \%$ [9-13].

Водночас недостатньо висвітленим $€$ питання надання стоматологічної допомоги таким дітям, проте вона вимагає певних особливостей, зумовлених швидкою втомлюваністю дітей, складністю контакту, затримкою фрізичного і психічного розвитку. Сьогодні для лікування і профрілактики карієсу й захворювань тканин пародонта в дітей із затримкою розумового розвитку використовуються традиційні схеми, які є лише умовним патогенетичним обґрунтуванням і не враховують особливостей перебігу основної хвороби. Тому лікувально-профрілактичні комплекси потребують удосконалення з урахуванням особливостей клінічного статусу дітей із окремими формами розумової відсталості, зокрема в дітей з олігофренією.

\section{Мета дослідження}

3 огляду на вищевикладене метою дослідження стали створення комплексу заходів для профрілактики карієсу зубів у дітей з олігофренією й оцінка його ефективності.

\section{Матеріали та методи дослідження}

Для оцінки ефективності профрілактичних заходів у динаміці протягом двох років спостерігали за 56 дітьми віком 12 років із олігофренією I ступеня тяжкості, які перебували на лікуванні в КЗ ЛОКПЛ: 27 дітей отримували створений нами профрілактичний комплекс, 29 дітей склали групу порівняння, профілактику карієсу цим дітям виконували за регіональними протоколами (гігієні- чне навчання, гігієна порожнини рота, використання фрторовмісних зубних паст).

Створений нами профілактичний комплекс охоплював екзогенні й ендогенні заходи. Перед початком лікувально-профрілактичних заходів усім дітям проводили гігієнічне навчання й виховання, професійну гігієну й санацію порожнини рота. Для індивідуальної гігієни рекомендували профрілактичні пасти, які сприяють ремінералізації емалі й містять сполуки фртору ("Lacalut Junior", "Sensodyne Pronamel Дитяча" та ін.).

Особливість проведення професійної гігієни в дітей з олігофренією полягала переважно в механічному видаленні зубних відкладень з обмеженим використанням ультразвукових скейлерів і попередньою підготовкою за допомогою седативних препаратів (екстракт валеріани, собача кропива (пустирник) тощо). Після проведення гігієни порожнини рота на зуби наносили фрторовмісний лак ("Bifluorid 12", "Фторплен").

Санація порожнини рота полягала в пломбуванні всіх наявних каріозних порожнин класичним або атравматичним (ART) методом, при цьому враховували особливості психосоматичного стану дітей (неконтакність і труднощі в спілкуванні, непосидючість, неадекватність і агресивність у поведінці) і особливостей клінічних проявів карієсу (переважно гострий перебіг каріозного процесу). 3 огляду на це перевагу віддавали склоіономерним цементам із покращеними фізичними й антимікробними властивостями («Equia Fil», «Miracle Mix», «Fuji VIII», «Fuji IX», «Ketac Molar Easy Mix» тощо).

Комплекс місцевих заходів із профілактики карієсу зубів охоплював герметизацію фісур; використання ремінералізувального гелю "Tooth Mousse" двічі за тиждень курсом 16-20 процедур; полоскання порожнини рота в домашніх умовах кальцієвмісними засобами ("Vitis Anticaries", "ApaCare Рідка емаль", "Biorepair" тощо) двічі за день зранку і ввечері після чищення зубів фтторовмісною пастою курсом 1 місяць.

У ролі ендогенної профрілактики рекомендували вживання «Цитра-Кальцеміну» по 1 таблетці 1 раз за день курсом 30 днів, «ЕхінацеїЛубнифарм» по 1 таблетці 1 раз за день курсом 10 днів, вітамінно-мінерального комплексу "Піковіт" по 1 таблетці 3 рази за день після їди протягом 1 місяця й корекцію харчування. Корекцію харчування в обстежених дітей проводили з ме- 
тою забезпечення організму необхідними макро, мікроелементами, вітамінами, для загального зміцнення організму, а також із метою зменшення вживання цукрів, м'якої борошняної їжі тощо. Для цього рекомендували вживання достатньої кількості ягід, овочів і фрруктів, бобових, круп (вівсянка, рис, гречка), молочних продуктів, морських водоростей (спіруліна, морська капуста, біологічно активні добавки "Зіравіт", "Ламінарин" тощо), зменшити вживання солодких напоїв, їжі, багатої на цукор, обмежити вживання хлібобулочних виробів.

Ураховуючи особливості перебігу олігофренії різних ступенів тяжкості, створений комплекс заходів застосовували в дітей із І ступенем олігофренії з періодичністю 2 рази за рік. Для дітей із II і III ступенями тяжкості основної хвороби було надано рекомендації з догляду за порожниною рота й профілактики карієсу зубів, які полягали в тому, що в дітей із II і III ступенями олігофренії гігієнічне навчання й виховання рекомендовано проводити в ігровій, доступній формі, з використанням методів для привертання уваги з обов'язковим наглядом медичного персоналу або батьків. Професійну гігієну доцільно обмежити тільки механічними засобами з попередньою підготовкою дитини седативними препаратами. Санацію порожнини рота доцільно проводити лише за допомогою ART-методики або з використанням загального знеболювання. Ремінералізувальні засоби рекомендовано застосовувати у вигляді полоскань або зрошувань порожнини рота.
Після завершення курсу лікувальнопрофрілактичних заходів рекомендували всім дітям проводити індивідуальну гігієну порожнини рота, використання профілактичних зубних паст із протикаріозною дією, ополіскувачів порожнини рота, корекцію харчування, а також огляд стоматолога щонайменше 2 рази за рік і професійну гігієну порожнини рота.

Ефективність створеного комплексу профілактичних заходів оцінювали через 6, 12 і 24 місяці за такими критеріями:

- приріст інтенсивності карієсу зубів; бів;

- редукція приросту інтенсивності карієсу зу-

- рівень гігієни порожнини рота (індекс OHI-S);

- зміни біоценозу порожнини рота (через 1 і 6 місяців спостереження).

\section{Результати дослідження та їх обговорення}

Результати обстеження показали, що через 6 місяців спостереження інтенсивність карієсу зу-

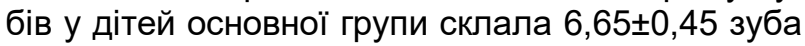
і була в 1,02 раза нижчою, ніж у дітей групи порівняння $(6,79 \pm 0,26$ зуба, $p>0,05)$ (рис. 1). Отже, приріст інтенсивності ураження карієсом зубів у дітей основної групи становив, у середньому, $0,41 \pm 0,05$ зуба, що значно нижче, ніж у дітей групи порівняння $(0,58 \pm 0,06$ зуба, р<0,05). Редукція приросту інтенсивності карієсу в дітей, яким проводили розпрацьовані профрілактичні заходи, склала $41,46 \%$.

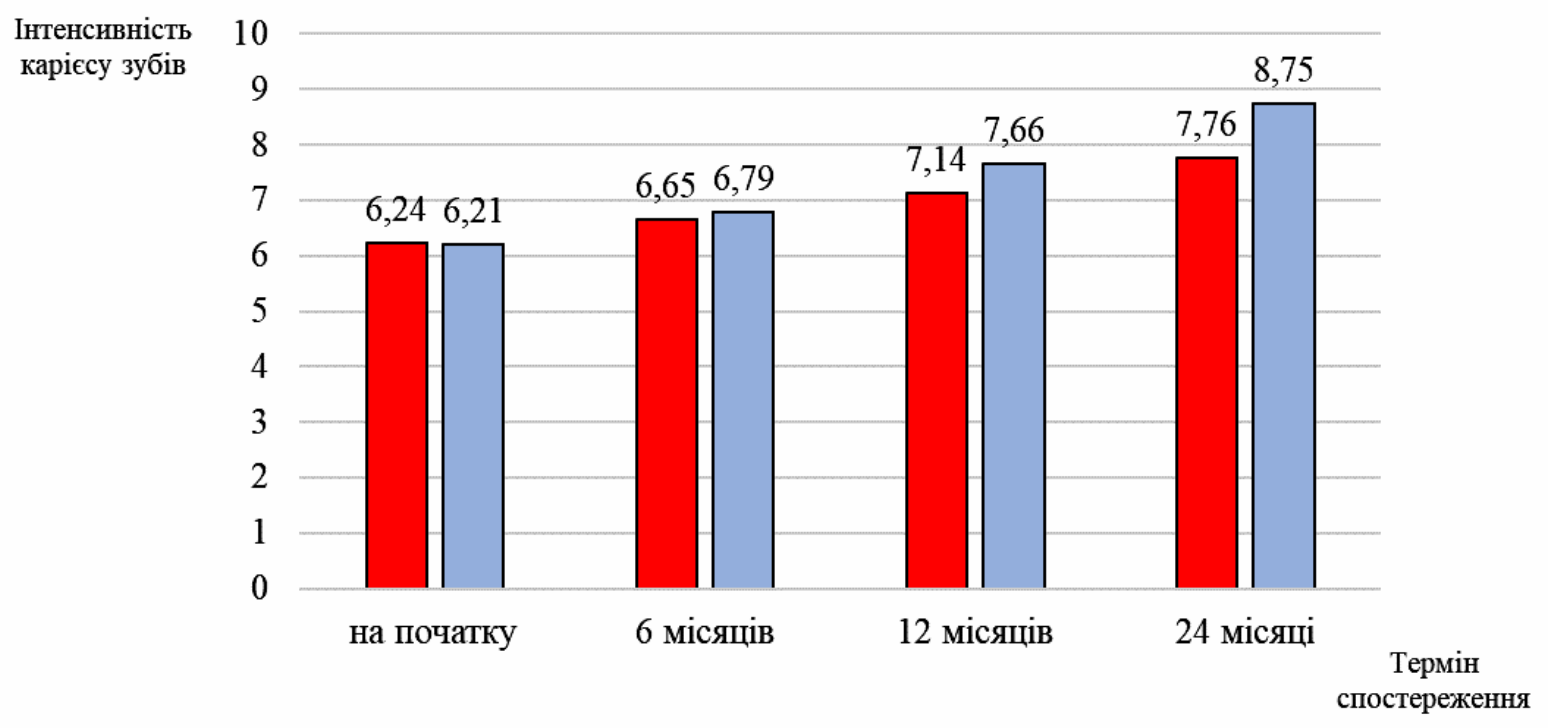

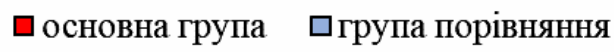

Puc. 1. Інтенсивність карієсу зубів у дітей із олігофрренією в різні терміни спостереження

Через 12 місяців спостереження інтенсивність карієсу зубів у дітей основної групи стано-

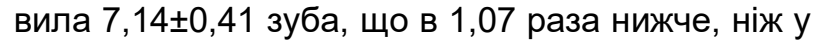
дітей групи порівняння $(7,66 \pm 0,29$ зуба, $р>0,05)$, тобто приріст інтенсивності карієсу у дітей, яким проводили профілактичні заходи згідно з розпрацьованим комплексом, складав, у середньо-

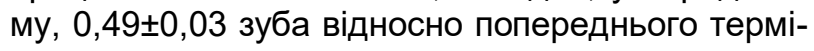

ну спостереження, натомість у дітей групи порі-

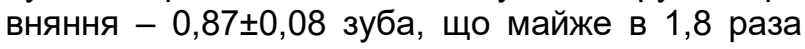
більше, ніж у дітей основної групи $(p<0,01)$. Редукція приросту інтенсивності карієсу в дітей, які отримували профрілактичний комплекс, через 12 місяців спостереження становила 43,67\%.

Через два роки після впровадження наших профілактичних заходів у дітей основної групи 
виявлено деяке підвищення приросту інтенсивності карієсу зубів у порівнянні з попереднім терміном спостереження. Отже, приріст інтенсивності карієсу в них становив, у середньому,

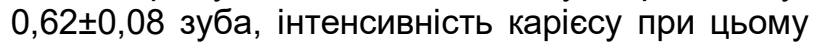

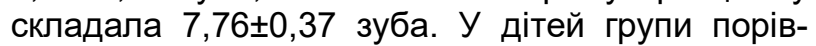
няння приріст інтенсивності карієсу перевищував значення, отримане в дітей основної групи, в 1,75 раза $(1,09 \pm 0,09$ зуба, $p<0,05)$, інтенсивність

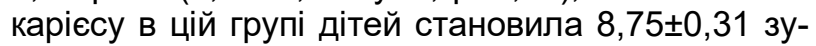
ба, що в 1,13 раза вище, ніж у дітей основної групи ( $<0,05)$. Редукція приросту інтенсивності карієсу в дітей основної групи становила

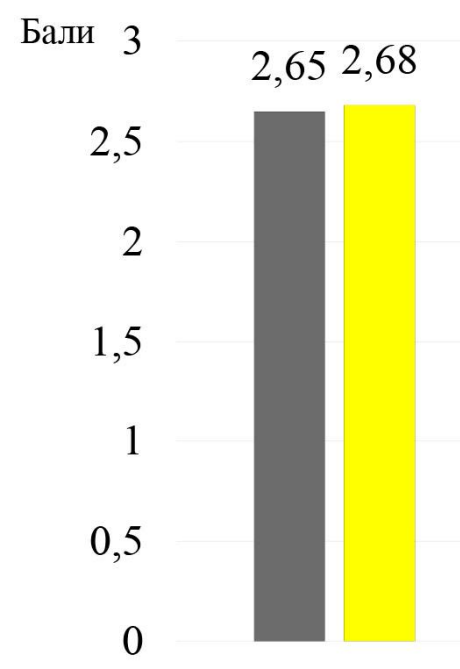

на початку

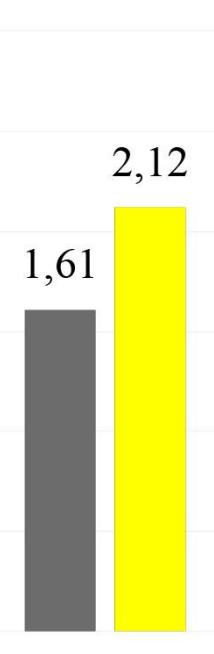

6 мiс
$43,12 \%$.

Отже, за два роки спостереження приріст інтенсивності карієсу в дітей основної групи складав 1,52 0,08 зуба і був у 1,74 раза нижчим, ніж у дітей групи порівняння $(2,64 \pm 0,9$ зуба, $p<0,05)$. Редукція приросту інтенсивності карієсу в дітей, які отримували профрілактичний комплекс, склала, у середньому, 42,42\%.

Ефективність запропонованого профілактичного комплексу для дітей із олігофренією за наявності каріозних уражень оцінювали також за допомогою гігієнічного індексу Гріна-Вермільона (рис. 2).

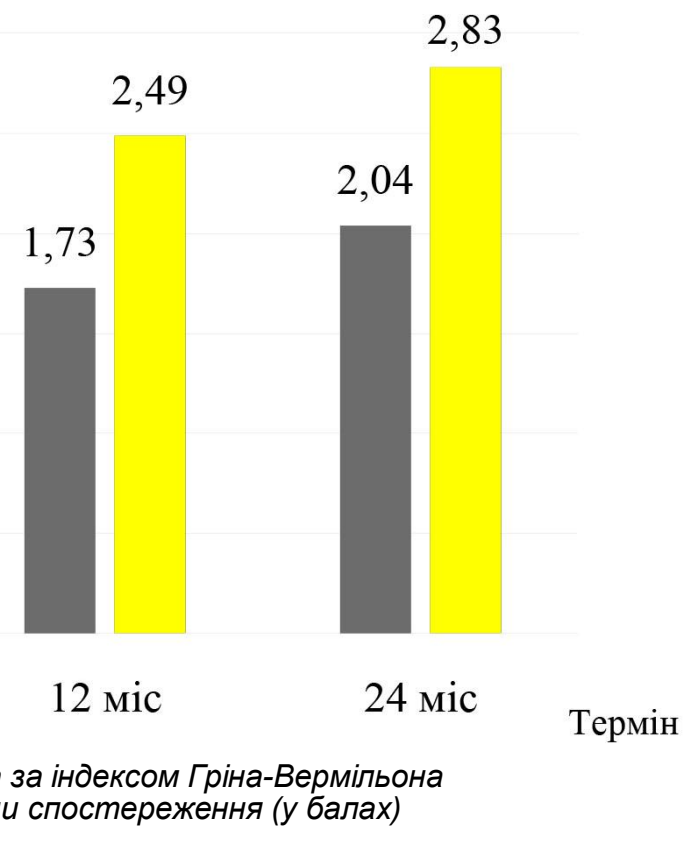

Як видно з даних, показаних на рисунку, до початку спостереження в дітей обох груп рівень гігієни порожнини рота був приблизно однаковим. Проте в динаміці проведення профілактичних заходів показники індексу гігієни в дітей основної групи і групи порівняння суттєво змінювались і відрізнялись.

Отже, до початку проведення комплексу профілактичних заходів рівень гігієни згідно з індексом OHI-S у дітей обох груп дослідження відповідав поганій гігієні порожнини рота. Через 6 місяців спостереження рівень гігієни порожнини рота в дітей основної групи розцінювався як задовільний і згідно з індексом OHI-S становив

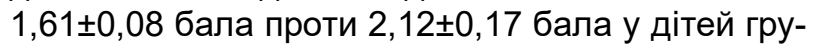
пи порівняння, що відповідає незадовільній гігієні порожнини рота $(p<0,05)$. Через рік після початку профілактики відбувалося погіршення стану гігієни порожнини рота в обох обстежуваних групах до незадовільного, при цьому різниця значень індексу OHI-S у дітей основної групи і групи порівняння була суттєвою $(1,73 \pm 0,10$ і $2,49 \pm 0,14$ бала відповідно, $p<0,05)$. За результатами, отриманими через два роки спостережен- ня, рівень гігієни порожнини рота в обстежених дітей також змінювався: у дітей основної групи

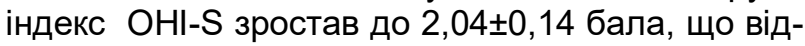
повідало незадовільній гігієні порожнини рота, проте в дітей групи порівняння його значення

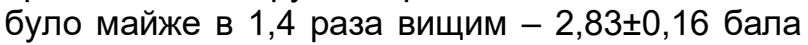
$(p<0,05)$, що відповідало поганому рівню гігієни порожнини рота.

Отже, після використання профрілактичного комплексу в дітей з олігофренією виявили кращий стан гігієни порожнини рота в порівнянні 3 дітьми групи порівняння, що може бути зумовлено, на нашу думку, проведенням професійної гігієни, контролем якості чищення зубів, а також гігієнічним навчанням дітей та їхніх батьків.

Про ефективність запропонованого лікувально-профілактичного комплексу свідчили також зміни біоценозу порожнини рота в обстежених дітей через 1 і 6 місяців спостереження. Результати мікробіологічних досліджень показали, що в дітей основної групи протягом періоду спостереження мікробний спектр ротової порожнини змінювався в позитивному напрямі (табл. 1). 
Динаміка мікробіоценозу порожнини рота дітей із олігофренією в різні терміни спостереження (у \%)

\begin{tabular}{|c|c|c|c|c|c|c|c|c|c|}
\hline \multicolumn{10}{|c|}{ Частота висівання мікроорганізмів } \\
\hline $\begin{array}{c}\text { Групи } \\
\text { спосте- } \\
\text { реження }\end{array}$ & $\begin{array}{c}\text { Lactobacill } \\
\text { aceae }\end{array}$ & $\begin{array}{l}\text { Micro- } \\
\text { coccus } \\
\text { spp. }\end{array}$ & $\begin{array}{c}\text { Str. } \\
\text { salivarius }\end{array}$ & $\begin{array}{c}\text { Str. } \\
\text { mutans }\end{array}$ & $\begin{array}{c}\text { Str. } \\
\text { sanguis }\end{array}$ & $\begin{array}{l}\text { Peptostre } \\
\text { ptococus }\end{array}$ & $\begin{array}{c}\text { Bacte- } \\
\text { rioidaceae } \\
\text { spp }\end{array}$ & Str.aureus & $\begin{array}{l}\text { Str.pyoge } \\
\text { nes }\end{array}$ \\
\hline \multicolumn{10}{|c|}{ На початку } \\
\hline основна & $\begin{array}{c}28,95 \pm \\
7,36\end{array}$ & $\begin{array}{c}21,05 \pm \\
6,61\end{array}$ & $\begin{array}{c}23,68 \pm \\
6,90 \\
\end{array}$ & $\begin{array}{c}78,95 \pm \\
6,61\end{array}$ & $\begin{array}{c}63,16 \pm \\
7,83\end{array}$ & $\begin{array}{c}65,79 \pm \\
7,70\end{array}$ & $\begin{array}{c}57,89 \pm \\
8,01\end{array}$ & $\begin{array}{c}71,05 \pm \\
7,36\end{array}$ & $\begin{array}{c}63,16 \pm \\
7,83 \\
\end{array}$ \\
\hline $\begin{array}{l}\text { група по- } \\
\text { рівняння }\end{array}$ & $\begin{array}{c}25,00 \pm \\
7,22\end{array}$ & $\begin{array}{c}19,44 \pm \\
6,60\end{array}$ & $\begin{array}{c}55,56 \pm \\
8,28\end{array}$ & $\begin{array}{c}63,89 \pm \\
8,01\end{array}$ & $\begin{array}{c}55,56 \pm \\
8,28\end{array}$ & $\begin{array}{c}69,44 \pm \\
7,68\end{array}$ & $\begin{array}{c}36,11 \pm \\
8,01\end{array}$ & $\begin{array}{c}4,44 \pm \\
8,28\end{array}$ & $\begin{array}{c}58,33 \pm \\
8,22 \\
\end{array}$ \\
\hline \multicolumn{10}{|c|}{ Через 1 місяць } \\
\hline основна & \begin{tabular}{|c}
$86,84 \pm 5,4$ \\
$8^{\star \star \#}$ \\
\end{tabular} & $\begin{array}{c}73,68 \pm 7,1 \\
4^{\star \star \# \#} \\
\end{array}$ & $\begin{array}{c}63,16 \pm 7,8 \\
3^{\# \#} \\
\end{array}$ & $\begin{array}{c}21,05 \pm 6,6 \\
1^{\# \#}\end{array}$ & $\begin{array}{c}26,32 \pm 7,1 \\
4^{\# \#} \\
\end{array}$ & $\begin{array}{c}23,68 \pm 6,9 \\
0^{\# \#}\end{array}$ & $\begin{array}{c}18,42 \pm 6,2 \\
9^{\# \#} \\
\end{array}$ & $\begin{array}{c}28,95 \pm 7,3 \\
6 \# \\
\end{array}$ & $\begin{array}{c}15,79 \pm 5,0 \\
2^{\# \#}\end{array}$ \\
\hline $\begin{array}{l}\text { група по- } \\
\text { рівняння }\end{array}$ & $\begin{array}{c}55,56 \pm \\
8,28^{\#} \\
\end{array}$ & $\begin{array}{c}30,56 \pm \\
7,68 \\
\end{array}$ & $\begin{array}{c}69,44 \pm \\
7,68 \\
\end{array}$ & $\begin{array}{c}38,89 \pm \\
8,12^{\#} \\
\end{array}$ & $\begin{array}{c}47,22 \pm \\
8,32 \\
\end{array}$ & $\begin{array}{c}38,89 \pm \\
8,12^{\#} \\
\end{array}$ & $\begin{array}{c}25,00 \pm \\
5,22 \\
\end{array}$ & $\begin{array}{c}25,00 \pm \\
5,22^{\#} \\
\end{array}$ & $\begin{array}{c}22,22 \pm \\
6,93^{\# \#}\end{array}$ \\
\hline \multicolumn{10}{|c|}{ Через 6 місяців } \\
\hline основна & $\begin{array}{c}81,58 \pm \\
6,29^{\star \star \# \#}\end{array}$ & $\begin{array}{l}78,95 \pm \\
6,61^{\star \#}\end{array}$ & $\begin{array}{l}68,42 \pm \\
7,54^{\star \# \#}\end{array}$ & $\begin{array}{l}13,16 \pm \\
4,48^{\star \#}\end{array}$ & $\begin{array}{l}15,79 \pm \\
5,02^{\star \#}\end{array}$ & $\begin{array}{c}18,42 \pm \\
6,29^{* * \#}\end{array}$ & $\begin{array}{c}15,79 \pm \\
5,02^{\star \star \# \#}\end{array}$ & $\begin{array}{c}18,42 \pm \\
6,29^{* \star \#}\end{array}$ & $\begin{array}{l}13,16 \pm \\
4,48^{\star \# \#}\end{array}$ \\
\hline $\begin{array}{l}\text { група по- } \\
\text { рівняння }\end{array}$ & $\begin{array}{c}44,44 \pm \\
8,28\end{array}$ & $\begin{array}{c}50,00 \pm \\
8,33^{\#}\end{array}$ & $\begin{array}{c}41,67 \pm \\
8,22\end{array}$ & $\begin{array}{l}36,11 \pm \\
8,01^{\# \#}\end{array}$ & $\begin{array}{c}41,67 \pm \\
8,22\end{array}$ & $\begin{array}{c}52,78 \pm \\
8,32\end{array}$ & $\begin{array}{c}47,22 \pm \\
8,32\end{array}$ & $\begin{array}{c}52,78 \pm \\
8,32\end{array}$ & $\begin{array}{c}38,89 \pm \\
8,12\end{array}$ \\
\hline
\end{tabular}

Примітки: 1. * - достовірність різниці між показниками основної групи і групи порівняння $p<0,05 ;{ }^{* *}-p<0,01$;

$$
\text { 2.\# - достовірність різниці між показниками на початку й у відповідні терміни спостереження } p<0,05 \text {; }
$$

Отже, через місяць спостереження в дітей основної групи зафріксовано значне збільшення кількості представників резидентної мікрофлори порожнини рота: кількість лактобактерій зростала в 3 рази (із $28,95 \pm 7,36 \%$ до $86,84 \pm 5,48 \%$, p<0,01); кількість мікроорганізмів-продуцентів каталази зростала в 3,5 раза, а відсотковий склад S. salivarius - автохтонного мікроорганізму ротової рідини і слизових оболонок збільшувався у 2,7 раза $(p<0,01)$, що перевищувало показники, отримані в групі порівняння: збільшення кількості лактобактерій у цих дітей відбувалося менш інтенсивно (із 25,00 $77,22 \%$ до $55,56 \pm 8,28 \%, p<0,05)$; кількість мікроорганізмівпродуцентів каталази зростала всього в 1,6 раза, а S. Salivarius - в 1,2 раза.

Протилежну тенденцію спостерігали щодо аеробної патогенної мікрофлори: через 1 місяць після початку застосування профрілактичних заходів у мікробіоценозі ротової порожнини дітей основної групи зафріксовано зниження в 3,75 раза відсотка бактерій основного карієсогенного виду S. mutans (із 78,95 $\pm 6,61 \%$ до $21,05 \pm 6,61 \%$, $p<0,01)$; відсоток патогенних $S$. sanguis знижувався у 2,4 раза $(p<0,01)$, тоді як у дітей групи порівняння зниження кількості $S$. mutans відбувалося в 1,6 раза (із $63,89 \pm 8,01 \%$ до $38,89 \pm 8,12 \%$, $\mathrm{p}<0,05)$, a $S$. sanguis - в 1,2 раза $(\mathrm{p}<0,05)$.

Через 6 місяців після використання комплексу профрілактичних заходів у дітей основної групи виявляли подальше поступове зменшення патогенної мікрофлори при зростанні кількості симбіотної. Так, уміст карієсогенного виду S. mutans знижувався із 78,95 $\pm 6,61 \%$ до $13,16 \pm 4,48 \%$, патогенного S. Sanguis - із $63,16 \pm 7,83 \%$ до $15,79 \pm 5,02 \% \quad(p<0,01)$. Зафріксовано достовірне зниження пептострептококів у 3,6 раза, бактеро- їдів - у 3,7 раза. Кількість гнійних стрептококів зменшувалась у 4,8 раза, золотистого стафілококу - у 3,9 раза $(p<0,01)$. У той же час у дітей групи порівняння зменшення кількості патогенної мікрофрлори відбувалося значно повільніше за меншого зростання симбіотної.

Отже, позитивна динаміка мікробного пейзажу порожнини рота в дітей із олігофренією, яким застосовували розпрацьований профілактичний комплекс, свідчить про ефективність його дії 3 урахуванням ступеня нормалізації біоценозу.

\section{Висновки}

Отже, спостереження за дітьми з олігофренією протягом двох років застосування комплексу заходів для профілактики карієсу зубів підтвердило ефективність запропонованого комплексу зниженням приросту інтенсивності карієсу, підвищенням редукції приросту інтенсивності карієсу, покращенням стану гігієни і стабілізацією показників мікробіоценозу порожнини рота.

\section{Список літератури}

1. Янчук АО, Скиба ВЯ, Катеринчук IП, Кузніченко СО, Скиба ОВ. Епідеміологічні дослідження та моніторинг стоматологічної захворюваності у дітей України. Світ медицини та біології. 2019;2(68):154-8.

2. Остапко ОІ. Стан тканин пародонта у дітей та підлітків, які проживають у різних регіонах України. Новини стоматології. 2015;1(82):78-83.

3. Каськова ЛФ, Мандзюк ТБ, Уласевич ЛП, Андріянова ОЮ, Янко НВ. Порівняльна характеристика показників карієсу у дітей різного шкільного віку. Буковинський медичний вісник. 2019;23(2):10-5.

4. Боднарук НІ. Вікові особливості ураженості карієсом тимчасових зубів у дітей з патологією опорно-рухового апарату. Вісник проблем біології i медицини. 2017;2(136):355-60. 
5. Костура ВЛ, Безвушко ЕВ. Поширеність та структура захворювань тканин пародонта у дітей із надмірною масою тіла. Клінічна стоматологія. 2017;2:42-7.

6. Смоляр НИ, Чухрай НЛ. Соматическая патология как фрактор, отягощающий фрормирование резистентности эмали постоянных зубов. Стоматология. 2017;6:44-7.

7. Боряк ОВ. Розумово відсталі діти як медикопсихологічна проблема. Педагогічні науки: теорія, історія, інноваційні технології. 2015;6(50):7485.

8. Войтко ВВ. Затримка психічного розвитку в контексті наукових досліджень. Науковий огляд. 2016;9(30):3-12.

9. Авраамова ОГ, Пахомова ЮВ. Стоматологический статус у умственно отсталых детей, проживающих в детском коллективе. Стоматология. 2016;95(3):52-5.

10. Боднарук ЮБ. Особливості перебігу та лікування хронічного катарального гінгівіту у дітей, хворих на дитячий церебральний параліч [автореферат]. Івано-Франківськ:. Івано-Франківс. нац. мед. ун-т., 2017. 20c.

11. Гавриленко МА. Оцінка стоматологічного статусу дітей-інвалідів із хворобами центральної нервової системи. Український стоматологічний альманах. 2014;2:82-4.

12. Ципан СБ, Якубова II, Бардавіль ДІ, Василенко OI, Жданова ТВ, Бакалінська СМ та ін. Поширеність захворювання тканин пародонта в дітей 3 розладами утистичного спектру. Профрілактична й дитяча стоматологія. 2020;1:78-84.

13. Пясецька ЛВ. Особливості перебігу та лікування захворювань тканин пародонта в осіб із різним психофізіологічним станом [автореферат]. Львів: Львів. нац. мед. ун-т ім. Данила Галицького; 2019. 20c

\section{References}

1. Janchuk $A O$, Skiba VJa, Katerinchuk IP, Kuznichenko SO, Skiba OV. Epidemiologichni doslidzhennja ta monitoring stomatologichnoï zahvorjuvanosti u ditej Ukraïni. Svit medicini ta biologiï. 2019;2(68):154-8. (Ukrainian).

2. Ostapko Ol. Stan tkanin parodonta u ditej ta pidlitkiv, jaki prozhivajut' u riznih regionah Ukraïni. Novini stomatologiï. 2015;1(82):78-83. (Ukrainian).

3. Kas'kova LF, Mandzjuk TB, Ulasevich LP, Andrijanova OJu, Janko NV. Porivnjal'na harakteristika pokaznikiv kariesu u ditej riznogo shkil'nogo viku. Bukovins'kij medichnij visnik. 2019;23(2):10-5. (Ukrainian).

4. Bodnaruk NI. Vikovi osoblivosti urazhenosti kariesom timchasovih zubiv u ditej $\mathrm{z}$ patologieju oporno-ruhovogo aparatu. Visnik problem biologiï i medicini. 2017;2(136):355-60. (Ukrainian).

5. Kostura VL, Bezvushko EV. Poshirenist' ta struktura zahvorjuvan' tkanin parodonta u ditej iz nadmirnoju masoju tila. Klinichna stomatologija. 2017;2:42-7. (Ukrainian).

6. Smoljar NI, Chuhraj NL. Somaticheskaja patologija kak faktor, otjagoshhajushij formirovanie rezistentnosti jemali postojannyh zubov. Stomatologija. 2017;6:44-7. (Russian).

7. Borjak OV. Rozumovo vidstali diti jak medikopsihologichna problema. Pedagogichni nauki: teorija, istorija, innovacijni tehnologiï. 2015;6(50):7485. (Ukrainian).

8. Vojtko VV. Zatrimka psihichnogo rozvitku v konteksti naukovih doslidzhen'. Naukovij ogljad. 2016;9(30):3-12. (Ukrainian).

9. Avraamova OG, Pahomova JuV. Stomatologicheskij status u umstvenno otstalyh detej, prozhivajushhih v detskom kollektive. Stomatologija. 2016;95(3):52-5. (Russian).

10. Bodnaruk JuB. Osoblivosti perebigu ta likuvannja hronichnogo kataral'nogo gingivitu u ditej, hvorih na ditjachij cerebral'nij paralich [avtoreferat]. IvanoFrankivs'k:. Ivano-Frankivs. nac. med. un-t., 2017. 20 s. (Ukrainian).

11. Gavrilenko MA. Ocinka stomatologichnogo statusu ditej-invalidiv iz hvorobami central'noï nervovoï sistemi. Ukraïns'kij stomatologichnij al'manah. 2014;2:82-4. (Ukrainian).

12. Cipan SB, Jakubova II, Bardavil' DI, Vasilenko OI, Zhdanova TV, Bakalins'ka SM ta in. Poshirenist' zahvorjuvannja tkanin parodonta $v$ ditej $z$ rozladami utistichnogo spektru. Profilaktichna j ditjacha stomatologija. 2020;1:78-84. (Ukrainian).

13. Pjasec'ka LV. Osoblivosti perebigu ta likuvannja zahvorjuvan' tkanin parodonta $v$ osib iz riznim psihofiziologichnim stanom [avtoreferat]. L'viv: L'viv. nac. med. un-t im. Danila Galic'kogo; 2019. 20 s. (Ukrainian).

Стаття надійшла: 2.08.2021 року.

\section{Резюме}

Для лікування і профрілактики стоматологічних хвороб у дітей із затримкою розумового розвитку використовуються традиційні схеми, відповідно лікувально-профілактичні комплекси потребують удосконалення з урахуванням особливостей клінічного статусу дітей із психоневрологічними розладами. Для оцінки ефективності профілактичних заходів у динаміці протягом 2 років під спостереженням перебували 56 дітей віком 12 років із олігофренією І ступеня тяжкості: 27 дітей отримували розпрацьований нами профілактичний комплекс, а 29 дітей склали групу порівняння. Застосування комплексу заходів для профілактики карієсу зубів у дітей з олігофренією протягом двох років підтвердило ефективність запропонованого комплексу зниженням приросту інтенсивності карієсу, підвищенням редукції приросту інтенсивності карієсу, покращенням стану гігієни і стабілізацією показників мікробіоценозу порожнини рота.

Ключові слова: карієс, діти, лікувально-профілактичний комплекс, психоневрологічні хвороби, мікробіоценоз. 


\title{
PECULIARITIES OF DENTAL CARIES PREVENTION IN CHILDREN WITH OLIGOPHRENIA
}

\author{
Chukhray N.L. ${ }^{1}$, Bezvushko E.V. ${ }^{1}$, Dutko G.Z. ${ }^{2}$, Stadnyk U.O. ${ }^{1}$, Musiy-Sementsiv Kh.H. ${ }^{1}$ \\ ${ }^{1}$ Danylo Halytskiy Lviv National Medical University, Lviv, Ukraine \\ ${ }^{2}$ Communal non-profit enterprise "Dental Clinic №4", Lviv, Ukraine
}

\section{Summary}

Nowadays dental caries and periodontal diseases are among the most pressing problems in Paediatric Dentistry. Young patients with psychoneurological disorders are a special category among children with somatic pathology. At the same time, the issue of providing dental care to such children is underrepresented. Today, traditional schemes used for the prevention and treatment of caries and periodontal disease in children with mental retardation requires further improvement taking into account the clinical status of children with particular forms of mental retardation, including oligophrenia. Thus, the aim of our study was to develop and evaluate the effectiveness of a complex of measures to prevent dental caries in children with oligophrenia.

To assess the effectiveness of the elaborated preventive complex, 56 children aged 12 years with the diagnosis of oligophrenia of I degree of severity (mild mental backwardness) were under observation during 2 years; 27 children received the complex we developed. The group of comparison included 29 children; caries prevention measures for these children were based on regional protocols (hygienic education, keeping oral hygiene, use of fluoride toothpastes).

The effectiveness of the developed preventive complex was evaluated 6,12 and 24 months after the beginning of its implementation according to the following criteria: the growth of dental caries intensity; reduction in the growth of dental caries intensity; level of oral hygiene (OHI-S index); changes in the biocenosis of the oral cavity (in 1 and 6 months of the observation).

The results of the examination after the 6 month observation period have shown the dental caries intensity in children of the main group is $6.65 \pm 0.45$ teeth that is 1.02 times lower than in the children of the comparison group $(6.79 \pm 0.26$ teeth, $p>0.05)$. Thus, the growth of dental caries intensity in the children of the main group is, on average, $0.41 \pm 0.05$ tooth, which is significantly lower than in children of the comparison group $(0.58 \pm 0.06$ tooth, $\mathrm{p}<0.05)$.

The reduction in the growth of caries intensity in children who received the developed preventive complex was $41.46 \%$. Thus, during two years of the observation, the growth of caries intensity in children of the main group is $1.52 \pm 0.08$ tooth that is 1.74 times lower than in children of the comparison group $(2.64 \pm 0.9$ tooth, $\mathrm{p}<0,05)$. The reduction in the growth of caries intensity in children who received this preventive complex is, on average, $42.42 \%$.

The effectiveness of the proposed preventive complex for children with oligophrenia and carious lesions was also evaluated by using the hygienic Green-Vermillion index. According to the data obtained, at the period of inclusion into the study, the children in both groups demonstrated nearly the same indices of the oral hygiene. However, over the period of the study, the indices of the hygiene index between the children of the main group and the comparison group differed significantly. The application of preventive complex in children with oligophrenia resulted in better oral hygiene than in that the children of the comparison group. This can be explained by professional hygiene, quality control of toothbrushing and hygiene education of children and their parents. The effectiveness of the elaborated complex of preventive measures was also evidenced by changes in the oral biocenosis in the children of the main group in 1 and 6 months of the observation. The findings of microbiological studies showed that the microbial spectrum of the oral cavity changed toward the healthier balance in the children of the main group during the observation period: there was gradual decrease in pathogenic microflora and an increase in symbiotic microflora.

Thus, the analysis of findings obtained over the two year observation period in children with oligophrenia, who received the complex of measures to prevent dental caries prevention has confirmed its effectiveness by reducing the growth of caries intensity, the reduction in the growth of caries intensity, hygiene improvement and normalization of oral microbiocenosis.

Key words: caries, children, therapeutic and preventive complex, psychoneurological diseases, oral microbiocenosis. 